\title{
HJELP PASIENTENE DINE MED RøYKESLUTT
}

Helsebiblioteket har over tid samlet mye stoff om tobakk, røyking og røykeslutt. Via helsebiblioteket.no har du fri tilgang til nyttige ressurser om emnet.

Tekst: Runar Eggen, Helsebiblioteket

Kampen mot tobakken er ikke helt over ennå, men du kan bidra.

Røykeslutt regnes som ett av de viktigste helsefremmende tiltakene hvor helsepersonell kan bidra. Hvordan kan du finne effektive strategier for å hjelpe pasientene med dette?

\section{HJELPEMIDLER}

I de kliniske oppslagsverkene BMJ Best Practice og UpToDate finner du nyttig stoff om hvordan du kan hjelpe pasientene dine til et tobakksfritt liv. UpToDate har blant annet en artikkel «Management of smoking cessation», som går gjennom ulike strategier for røykeslutt. Best Practice gir deg tips om hvordan du legger opp arbeidet i klinikken for å få pasientene dine til å stumpe røyken - søk på «smoking cessation» i oppslagsverket som du finner øverst til høyre på Helsebibliotekets hovedside.

\section{SAMFUNNSPROBLEM}

Helsebiblioteket.no har to undersider som omhandler tobakk. Den ene finner du under Emnebibliotek samfunnsmedisin og folkehelse. Her finner du statistikk, faktaopplysninger om snus, nummeret til tobakkstelefonen og mye annet nyttig stoff, under tema «tobakk». Samme sted har vi samlet de viktigste norske rapportene om emnet. Her finner du blant annet rapporter om hvor effektive myndighetenes tiltak mot røyking har vært. Du finner også praktisk hjelp for å snakke med pasientene om røykeslutt. 


\section{AVHENGIGHETSPROBLEM}

Ønsker du å lese om røyking som avhengighetsproblem, er Emnebibliotek psykisk helses sider om rus og avhengighet et godt utgangspunkt. Siden om oppsummert forskning vil være spesielt nyttig.

\section{RøYKESLUTT PÅ ARBEIDSPLASSEN}

Ønsker du å organisere en røykesluttkampanje på arbeidsplassen, finner du gode tips i artikkelen «Kunnskapsbasert røykeslutt», denne finner du ved å søke på tittelen i Helsebiblioteket.

\section{FAGLIG OPPDATERING}

Det finnes flere tidsskrifter som kan være interessante å følge med på for den som arbeider med tobakksproblematikk.

Helsebiblioteket abonnerer på disse tidsskriftene:

- Tobacco Control

- Tobacco Induced Diseases

- Psychology of Addictive Behaviors



